\title{
Immunization with synthetic peptides containing epitopes of the class 1 outer-membrane protein of Neisseria meningitidis: production of bactericidal antibodies on immunization with a cyclic peptide
}

\author{
Myron Christodoulides,* Brian T. McGuinness $\dagger$ and John E. Heckels \\ Molecular Microbiology Group, University of Southampton Medical School, Southampton General Hospital, \\ Tremona Road, Southampton SO9 $4 X Y$, UK
}

(Received 15 January 1993; revised 2 March 1993; accepted 4 May 1993)

\begin{abstract}
The class 1 outer-membrane protein of Neisseria menigitidis is the target for subtype-specific, bactericidal monoclonal antibodies (mAbs). The epitopes recognized by these antibodies have been mapped previously to linear peptides corresponding to the sequences thought to be exposed at the apices of surface-exposed loops of the protein. In this work several synthetic peptides containing the subtype Pl.16b epitope have been synthetized with the aim of inducing a polyclonal immune response resembling the reactivity of the mAbs. Initially, peptides of 9 and 15 amino acid residues were synthesized and used for immunization after coupling to a carrier protein. The reactivity of the resulting antisera, with synthetic linear decapeptides, resembled that seen in previous epitope mapping experiments with the protective mAbs. However, despite the induction of antibodies having the desired specificity, the antisera reacted poorly with the native protein in outer membranes, and were non-bactericidal. A 36mer peptide, consisting of the entire surface-exposed loop 4 of the class 1 protein was then synthesized and used for immunization as (i) free peptide, (ii) peptide coupled to carrier and (iii) peptide subjected to cyclization, in an attempt to restrict it to conformations that might more closely resemble the native loop structure. In contrast to antisera raised against linear peptides, antibodies raised by immunization with the 36mer cyclic peptide, did not react with linear peptides recognized by the $\mathrm{mAbs}$, but instead appeared to recognize conformational determinants. This antiserum promoted complement-mediated bactericidal killing of the homologous meningococcal strain, demonstrating the potential of synthetic peptide immunogens for inducing a protective immune response against group B meningococci.
\end{abstract}

\section{Introduction}

A continuing need exists for an effective vaccine against meningococcal meningitis. Current vaccines, based on the group-specific capsular polysaccharides, provide short-term protection in adults against serogroups $A$ and $C$, but are ineffective in infants. In addition, these vaccines afford no protection against group B strains, the predominant cause of infection in most temperate

*Author for correspondence. Tel. 0703 796974; fax. (0703) 774316; e-mail JEH@UK.AC.SOUTHAMPTON.MAIL.

$\dagger$ Present address: Cambridge Antibody Technology Ltd, The Science Park, Melbourn, Cambridgeshire SG8 6EJ, UK.

Abbreviations: KLH, keyhole limpet haemocyanin; mAb, monoclonal antibody; OM, outer membrane. countries. Currently, new experimental vaccines based on outer-membrane proteins are under investigation. This strategy is based on observations that antibodies directed against meningococcal outer-membrane proteins activate complement and kill encapsulated strains (Frasch, 1985).

Four major classes of meningococcal outer-membrane proteins have been identified, namely the class $1,2 / 3,4$ and 5 proteins (Tsai et al., 1981). The class 5 proteins are hypervariable, undergoing antigenic shift during infection (Tinsley \& Heckels, 1986), whereas the class 4 protein is antigenically stable but can induce antibodies which are not only non-bactericidal but which may block the bactericidal effect of antibodies directed against other surface antigens (Munkley et al., 1991). In contrast, the class 1 and class $2 / 3$ proteins are stable within a strain and are the targets for bactericidal monoclonal antibodies (mAbs) (Saukkonen et al., 1989). The design of 
Table 1. Synthetic peptides used for immunization

\begin{tabular}{lll}
\hline \hline Peptide & \multicolumn{1}{c}{ Sequence } & Peptide immunogen \\
\hline $9 \mathrm{~N}$ & TKNTNNNLC & $9 \mathrm{~N}-\mathrm{KLH}$ \\
$15 \mathrm{~N}$ & TKNTNNNLTLVPAVC & $15 \mathrm{~N}-\mathrm{KLH}$ \\
$36 \mathrm{~N}$ & CPIQNSKSAYTPAYYTKNTNNNLTLVPAVVGKPGSC & $\begin{array}{l}36 \mathrm{~N}-\mathrm{KLH} \\
36 \mathrm{~N} \text { (carboxymethylated) } \\
\mathrm{C}-36 \mathrm{~N} \text { (cyclic) }\end{array}$ \\
\hline \hline
\end{tabular}

current vaccines is based on methods that lead to the enrichment of these proteins from outer-membrane preparations (Frasch, 1985; Bjune et al., 1991; Zollinger et al., 1991).

The class 1 protein, which is responsible for meningococcal subtype specificity, appears to be particularly effective in generating a protective immune response. $\mathrm{mAbs}$ directed against the class 1 protein have been found to be the most effective in passive protection against infection, in an experimental infant rat model (Saukkonen et al., 1989). In addition, the bactericidal activity in sera from volunteers immunized with the experimental vaccines appears, at least in part, to be associated with the production of anti-class 1 protein antibodies (Wedege \& Froholm, 1986; Zollinger et al., 1991).

The sequence of the genes (por $\mathrm{A}$ ) encoding the class 1 proteins have now been determined for a number of strains of different subtype (McGuinness et al., 1990, 1993; Maiden et al., 1991). Comparison of the predicted amino acid sequences reveals that sequence variation is largely confined to two discrete variable regions designated VR1 and VR2. This sequence information has also led to a model for the organization of the protein within the outer membrane (van der Ley et al., 1991), in which a series of conserved regions form amphipathic transmembrane $\beta$-sheets and generate eight surface-exposed hydrophilic loops. The model predicts loops 1 and 4 to be the longest and to contain the variable regions VR1 and VR2, respectively.

Epitope mapping studies with synthetic peptides have localized the epitopes recognized by the protective mAbs to apices of these loops (McGuinness et al., 1990, 1993). Thus, a mAb with P1.16 subtype specificity reacts with the peptide TKDTNNNLTL, corresponding to the sequence at the apex of loop 4 . In addition, analysis of the class 1 protein from an isolate associated with an epidemic of meningococcal infection in Gloucestershire, England, has revealed the presence of a point mutation in the por $A$ gene generating a single amino acid substitution of $\mathrm{D}$ to $\mathrm{N}$ in the epitope. This substitution results in a class 1 protein (P1.16b) with substantially altered antigenic properties (McGuinness et al., 1990). Such studies demonstrate the critical influence on antigenicity of discrete regions representing only a small portion of the protein.

Recent studies with experimental outer-membrane vaccines indicate the need to direct the immune response specifically towards those epitopes that can induce protective bactericidal antibodies (Zollinger et al., 1991). The knowledge of the structure and immunochemistry of the class 1 protein, make it a particularly attractive candidate for such studies, using synthetic peptides as vaccines designed to focus the immune response to defined, protective epitopes. In the current studies, we have chosen as a model the subtype P1.16b strain of meningococcus isolated from an epidemic of meningococcal infection in Gloucestershire, England, and have synthesized several synthetic peptides containing the P1.16b epitope for investigation as experimental subunit vaccines, with respect to their immunogenicity, and the antigenic and biological activity of the antibodies induced.

\section{Methods}

Bacterial strains. Neisseria meningitidis strains MC50 (C:NT:P1.16) and MC58 (B:15:P.17,16b), an isolate from the Gloucester area have been described previously (Tinsley \& Heckels, 1986). Strain H44/76 (B:15:P1.7,16) is the subtype P1.7,16 reference strain (Frasch et al. 1985). All strains were grown on protease-peptone agar at $37^{\circ} \mathrm{C}$ for $18 \mathrm{~h}$ in an atmosphere of $5 \%(\mathrm{v} / \mathrm{v}) \mathrm{CO}_{2}$ (Tinsley \& Heckels, 1986).

Outer membranes (OMs). OMs were prepared by extraction of whole cells with lithium acetate as described previously (Tinsley \& Heckels, 1986).

\section{Synthetic Peptides}

(i) Solid phase peptide synthesis. Peptides (Table 1) were synthesized using solid-phase chemistry. In initial studies peptide synthesis was carried out manually with the RAMPS Multiple Peptide Synthesis System (DuPont) as described previously (Heckels et al., 1990). Subsequent syntheses were carried out on an Applied Biosystems Model 431A Peptide Synthesizer. Peptides were synthesized on 4-(hydroxymethyl)-phenoxymethyl copolystyrene- $1 \%$ divinylbenzene (HMP) resin, with $N$ - $\alpha$-(9-fluorenylmethyloxycarbonyl) (FMOC)-protected amino acids with $t$-butyl side-chain protection, except for cysteine and asparagine (trityl-), and lysine [ $\mathrm{N}$-t-butoxycarbonyl(BOC-)]. Activation and coupling was done in the presence of hydroxybenzotriazole/dicyclohexylcarbodiimide, and peptides were acetylated at the $\mathrm{N}$ terminus with acetic anhydride. Deprotection and cleavage of peptide from the solid support was done in trifluoroacetic acid (TFA)/water/ethanedithiol (95:2.5:2.5 by vol.). Peptides were recovered by precipitation with ether. 
The crude peptides were washed with ether and purified by HPLC on a semi-preparative Zorbax C8 column using a gradient of 5-80\% (v/v) acetonitrile in water containing $0.1 \%$ TFA. Purified peptides were lyophilized and stored at $-20^{\circ} \mathrm{C}$. Composition was assessed by amino acid analysis using an automated amino acid analyser (Applied Biosystems).

(ii) Peptide carboxymethylation. The cysteinyl thiol groups of peptide $36 \mathrm{~N}$ were reduced with 2-mercaptoethanol and carboxymethylated with iodoacetamide as described by Lambden et al. (1981).

(iii) Peptide cyclization. Peptide $36 \mathrm{~N}$ was cyclized by oxidation of free cysteinyl thiol groups essentially as described by Tam \& Lu (1989). Peptide $\left(0 \cdot 1 \mathrm{mg} \mathrm{m}^{-1}\right)$ was reacted for $1 \mathrm{~h}$ at $0{ }^{\circ} \mathrm{C}$ with iodine $(1 \mathrm{~mm}$ in methanol) and the oxidation was then quenched with sodium thiosulphate. The mixture was subjected to reverse-phase HPLC on a semi-preparative Zorbax $\mathrm{C} 8$ column, followed by gel filtration on a Zorbax GF250 column. Two peaks which were separated by the gel filtration step were further analysed by mass spectroscopy, using an Applied Biosystems BioIon 20 Biopolymer plasma desorption time-offlight Mass Analyzer. The first peak was resolved by mass analysis into two species, a partially protected monomer peptide and a dimeric peptide. Mass analysis of the second peak showed a single homogeneous species of monomeric peptide. This material tested negative for free cysteine thiol groups with Ellman's reagent [5,5-dithio-bis(2nitrobenzoic acid); Sigma] at the highest concentration of peptide before saturation $\left(20 \mathrm{mg} \mathrm{m}^{-1}\right)$. This peak thus represented the cyclic peptide and was stored at $\mathrm{pH} 4.0$ at $-20^{\circ} \mathrm{C}$ until used.

Production of peptide-protein conjugates. Synthetic peptides were coupled to carrier protein keyhole limpet haemocyanin (KLH; Sigma) through the C-terminal cysteine of the peptide using the heterobifunctional reagent $N$ - $\gamma$-maleimidobutyric acid $N$-hydroxysuccinimide ester (GMBS; Sigma). Carrier protein [4 $\mathrm{mg} \mathrm{KLH} \mathrm{ml}^{-1}$ in $100 \mu \mathrm{l}$ phosphate buffered saline (PBS) $\mathrm{pH} 7.4$ ] was activated by reaction with GMBS $\left(0.5 \mathrm{mg}\right.$ per $5 \mu \mathrm{l}$ dimethylformamide) for $1 \mathrm{~h}$ at $25^{\circ} \mathrm{C}$ under nitrogen gas. The activated protein was separated from excess GMBS by gel filtration on Sephadex G25 (Pharmacia). Column fractions containing the carrier protein (monitored by $A_{280}$ ) were pooled, and added to $4 \mathrm{mg}$ peptide dissolved in an equivalent volume of PBS. The mixture was gassed with nitrogen, and incubated at $25^{\circ} \mathrm{C}$ for $3 \mathrm{~h}$ with gentle stirring.

The progress of the conjugation was monitored colorimetrically from reactivity of free cysteine thiol groups with Ellman's reagent. Coupling was complete when no colour change was observed. The carrier-conjugated peptides were stored at $-20^{\circ} \mathrm{C}$ until used.

Multiple solid-phase peptide synthesis and epitope mapping. Multiple solid-phase peptides were synthesized using pin technology according to the manufacturer's instructions with a commercially available kit (Cambridge Research Biochemicals). The solid-phase supports were polyethylene pins, each of which had a $N$ - $\alpha$-FMOC-protected $\beta$-alanine residue coupled via a flexible linker of 1,6-diaminohexane and polyacrylic acid (Geysen et al., 1987). Synthesis used pentafluorophenyl (pfp)-activated esters of FMOC-L-amino acids with $t$-butyl side-chain protection (Milligen), except for arginine (methoxytrimethylphenylsulphonyl side-chain), and serine and threonine which were used as oxabenzatriazine active esters. Each synthesis was performed in duplicate and after completion, the terminal amino group was acetylated and the side-chain protecting groups were removed in TFA/phenol/ethanedithiol $(95: 2 \cdot 5: 2 \cdot 5 \mathrm{v} / \mathrm{v})$ as described previously (Virji \& Heckels, 1989). On each occasion, peptide controls were synthesized and reacted with $\mathrm{mAb}$ SM300 which recognizes sequence TKDTNNNLTL, but not TKNTNNNLTL.

The multiple peptide pins were used for epitope mapping of sera as follows. Briefly, the pins were blocked in PBS containing $1 \%(\mathrm{w} / \mathrm{v})$ ovalbumin, $1 \%(\mathrm{w} / \mathrm{v})$ BSA and $0.1 \%(\mathrm{v} / \mathrm{v})$ Tween- 20 for $1 \mathrm{~h}$ at $25^{\circ} \mathrm{C}$. Test anterisa were diluted (1:500) in blocking buffer, and reacted with the pins at $4{ }^{\circ} \mathrm{C}$ overnight. The pins were washed, then reacted with horseradish peroxidase-conjugated goat anti-rabbit Ig for $1 \mathrm{~h}$ at $25^{\circ} \mathrm{C}$, and transferred to substrate solution [2,2'-azino-bis(3-ethylbenzthiazoline-6-sulphonate) (ABTS) and $\mathrm{H}_{2} \mathrm{O}_{2}$ for $30 \mathrm{~min}$ at $25^{\circ} \mathrm{C}$ in the dark. Absorbance readings at $405 \mathrm{~nm}$ were taken at 10 and $30 \mathrm{~min}$. Pins were regenerated by sonication at $60^{\circ} \mathrm{C}$ for $30 \mathrm{~min}$ in $0.1 \mathrm{M}$-sodium phosphate buffer, $\mathrm{pH} 7 \cdot 2$, containing $0.1 \%(\mathrm{w} / \mathrm{v})$ SDS and $0.1 \%(\mathrm{v} / \mathrm{v})$ 2-mercaptoethanol, followed by subsequent washing with warm distilled water and boiling in methanol $(100 \%)$ as described previously (Virji \& Heckels, 1989).

Immunization of animals. New Zealand half-lop rabbits were housed under standard conditions of temperature and humidity with a $12 \mathrm{~h}$ lightning cycle, and with food and water available ad libitum. The rabbits were each immunized subcutaneously on day 1 with $25 \mu \mathrm{g}$ of antigen emulsified in Freund's Complete Adjuvant (Sigma) distributed between 2 and 3 sites, and on days 14 and 28 with the same preparation(s) emulsified in Freund's Incomplete Adjuvant (Sigma). Test bleeds were taken 7-10 d later to monitor levels of circulating antipeptide antibodies by ELISA. Up to three further booster immunizations were given at approximately $14 \mathrm{~d}$ intervals, after which the animals were terminally bled and the sera stored at $-20^{\circ} \mathrm{C}$ until used.

\section{Detection of immune response}

(i) ELISA. Flat-bottomed microtitre plates (Sterilin) were coated overnight at $37^{\circ} \mathrm{C}$ with antigen $\left(1 \mu \mathrm{g} \mathrm{ml}^{-1}\right)$ in $0.05 \mathrm{M}$-sodium carbonate buffer, $\mathrm{pH}$ 9.6. Test antisera were serially diluted in PBS containing Tween-20 (0.05\% v/v) (PBST) containing 1\% (w/v) BSA and the plates were incubated for $1 \mathrm{~h}$ at $37^{\circ} \mathrm{C}$. After washing, antibody binding was detected using horseradish peroxidase-conjugated goat anti-rabbit Ig (Bio-Rad) with 3,3',5,5'-tetramethylbenzidine and $\mathrm{H}_{2} \mathrm{O}_{2}$ as enzyme substrate. Absorbance was measured at $450 \mathrm{~nm}$ and the ELISA titre was extrapolated from the linear portion of the titration curve and taken as the reciprocal dilution which gave an absorbance increase of $0 \cdot 1 \mathrm{~h}^{-1}$.

(ii) SDS-PAGE and Western blotting. SDS-PAGE was performed using a $10-25 \%(\mathrm{w} / \mathrm{v})$ acrylamide gradient as described previously (Heckels, 1981). Outer-membrane protein preparations of strains MC50 and MC58 were separated on preparative gels (250 $\mu$ g total protein), and proteins transferred to nitrocellulose paper (Schleicher and Schuell BA85, 0.45 $\mu \mathrm{m}$ ) using a Trans-Blot Semi-Dry transfer cell (Bio-Rad) as described previously (McGuinness et al., 1993). The nitrocellulose sheet was washed twice in Tris-buffered saline, $\mathrm{pH} 7 \cdot 5$, containing $0.05 \%(\mathrm{v} / \mathrm{v})$ Tween-20 (TBST) and blocked in TBST containing $5 \%(\mathrm{w} / \mathrm{v})$ skimmed milk powder for $1 \mathrm{~h}$ at $25^{\circ} \mathrm{C}$. Serial dilutions of antisera were made in TBST containing $1 \%(\mathrm{w} / \mathrm{v})$ gelatin and added to the strips which were then incubated for $1 \mathrm{~h}$ at $25^{\circ} \mathrm{C}$. After washing, the strips were reacted for $1 \mathrm{~h}$ at $25^{\circ} \mathrm{C}$ with alkaline phosphatase-conjugated goat anti-rabbit Ig (Bio-Rad) diluted 1:2000 in TBST containing $5 \%(\mathrm{w} / \mathrm{v})$ skimmed milk powder. Immunological reactivity was detected with substrate solution containing nitro-bluetetrazolium and 5-bromo-4-chloro-3-indolylphosphate (Bio-Rad) according to the manufacturer's instructions.

Bactericidal killing assays. The bactericidal activity of the antisera raised was determined essentially as described by Munkley et al. (1991) using guinea pig serum as a source of exogenous complement. Meningococcal strains MC58 or MC50 were harvested into Dulbecco B phosphate buffered saline (PBSB) containing $1 \%(\mathrm{v} / \mathrm{v})$ heatinactivated $\left(56^{\circ} \mathrm{C}, 30 \mathrm{~min}\right)$ foetal calf serum. Bacterial suspension ( $25 \mu$ l, containing approx. 1000 c.f.u.) was added to the wells of a sterile 96-well microtitre plate containing serial dilutions of decomplemented test antisera in PBSB $(10 \mu \mathrm{l})$. Freshly thawed complement or decomplemented serum was then added to a final concentration of $5 \%$ $(\mathrm{v} / \mathrm{v})$ and the plates were agitated briefly to ensure thorough mixing. 
Table 2. ELISA reactivity of antisera raised by immunization with synthetic peptides

Sera, pre- and post-immunization, were tested against the homologous immunizing peptide and against OMs of strains MC58 (P1.7,16b), MC50 (P1.16) and H44/76 (P1.7,16). Each serum was assayed three times and the mean reciprocal ELISA titre shown.

\begin{tabular}{|c|c|c|c|c|c|c|c|c|}
\hline \multirow{3}{*}{$\begin{array}{c}\text { Peptide } \\
\text { immunogen }\end{array}$} & \multicolumn{8}{|c|}{$10^{3} \times$ Reciprocal ELISA titre against antigen } \\
\hline & \multicolumn{2}{|c|}{$\begin{array}{l}\text { Homologous } \\
\text { peptide }\end{array}$} & \multicolumn{2}{|c|}{$\begin{array}{c}\text { MC58 } \\
\text { OM }\end{array}$} & \multicolumn{2}{|c|}{$\begin{array}{c}\mathrm{MC50} \\
\mathrm{OM}\end{array}$} & \multicolumn{2}{|c|}{$\begin{array}{c}\mathrm{H} 44 / 76 \\
\mathrm{OM}\end{array}$} \\
\hline & Pre- & Post- & Pre & Post- & Pre- & Post- & Pre- & Post- \\
\hline 9N-KLH & 2 & 16600 & 20 & 93 & 6 & 39 & 7 & 36 \\
\hline $15 \mathrm{~N}-\mathrm{KLH}$ & 1 & 950 & 2 & 38 & 3 & 64 & 17 & 45 \\
\hline 36N-KLH & 7 & 27400 & 10 & 230 & 4 & 70 & 6 & 2800 \\
\hline $36 \mathrm{~N}$ & 6 & 9700 & 27 & 240 & 10 & 43 & 17 & 1360 \\
\hline $\mathrm{C}-36 \mathrm{~N}$ & 2 & 660 & 57 & 110 & 7 & 31 & 9 & 160 \\
\hline
\end{tabular}

Samples $(15 \mu \mathrm{l})$ were taken from negative control wells (containing heat-inactivated serum) for each antiserum dilution tested, for c.f.u. at $t=0$. The plates were incubated at $37^{\circ} \mathrm{C}$ for $30 \mathrm{~min}$ in an atmosphere of $5 \%(\mathrm{v} / \mathrm{v}) \mathrm{CO}_{2}$, and then $15 \mu \mathrm{l}$ samples removed from each well for determination of surviving c.f.u. Each antiserum was tested in parallel with the homologous pre-immune serum to determine the non-specific bactericidal activity present in the serum. All sera, with and without exogenous complement, were assayed six times at each serial dilution.

The complement-mediated bactericidal activity of each antiserum compared to the corresponding pre-immune serum was analysed statistically using the following tests. An $F$-test was done to compare the variance of each population, and a two-sample $t$-test was used to determine whether the bactericidal activity of antiserum was significantly greater than pre-immune, background activity.

\section{Results}

Immunogenicity of synthetic peptides

Initially, a small (9mer, 9N) and intermediate $(15 \mathrm{mer}$, $15 \mathrm{~N})$ peptide containing the $\mathrm{P} 1.16 \mathrm{~b}$ epitope were synthesized (Table 1) and used for immunization after conjugation to KLH. Antisera raised against each of the conjugated peptides were then tested in ELISA against their corresponding homologous immunizing peptide. In each case the conjugates were highly immunogenic, eliciting a $10^{3}-10^{4}$-fold increase in anti-peptide antibody titre (Table 2).

To determine the ability of anti-peptide sera to recognize native class 1 protein, the sera were also reacted with OMs from three meningococcal strains MC58 (P1.7,16b), MC50 (P1.16) and H44/76 (P1.7,16). The $9 \mathrm{~N}-\mathrm{KLH}$ conjugate antisera showed approximately five-fold rises in titre against all three meningococcal OMs, while the $15 \mathrm{~N}-\mathrm{KLH}$ conjugate antisera showed approximately 5-20-fold rises in titre against all three strains (Table 2).

In an attempt to mimic the conformation of the native protein, a 36mer peptide was synthesized with the $\mathrm{P} 1.16 \mathrm{~b}$ epitope at its centre (Table 1). The peptide was used for immunization as a $\mathrm{KLH}$-conjugate $(36 \mathrm{~N}-\mathrm{KLH})$, as free peptide $(36 \mathrm{~N})$ and after cyclization $(\mathrm{C}-36 \mathrm{~N})$. The conjugate and both of the free peptides were immunogenic, eliciting a strong ELISA response to the immunizing peptide $\left(10^{3}-10^{4}\right.$-fold rise; Table 2$)$. The conjugate also induced significant increases $(20-500$-fold) in anti$\mathrm{OM}$ antibody levels. Sera raised against the free linear peptide showed lower increases in titre with OMs from all three meningococcal strains (4-80-fold rise), whilst antisera raised against the cyclic peptide showed 2-20-fold rises in titres.

\section{Epitope mapping of antisera}

To compare the immunogenicity of the peptides in detail, the sera were subjected to epitope mapping with overlapping decapeptides corresponding to the amino acid sequence of loop 4 of the class 1 outer-membrane protein. Peptides were synthesized on polyethylene pins with adjacent peptides differing by a single residue and contained either the $\mathrm{N}^{182}$ or $\mathrm{D}^{182}$ residue corresponding to the Pl.16b and Pl.16 epitopes, respectively, and each serum was reacted with the pins in ELISA. As might be expected with polyclonal sera, no precise epitopes could be defined with any of the sera, but general trends of reactivity could be clearly discerned, showing significant differences between the immunizing agents.

Immunization with the 9 mer and 15 mer conjugates produced antisera with broadly similar reactivities. The antisera to $9 \mathrm{~N}-\mathrm{KLH}$ reacted with the adjacent peptides from ${ }^{175}$ TPAYYTKNTN ${ }^{184}$ through to ${ }^{183}$ TNNNLTLVPA ${ }^{192}$, and reacted equally well with the equivalent peptides containing the $\mathrm{D}^{182}$ amino acid substitution (Fig. 1a). The sera raised against the $15 \mathrm{mer}$ 

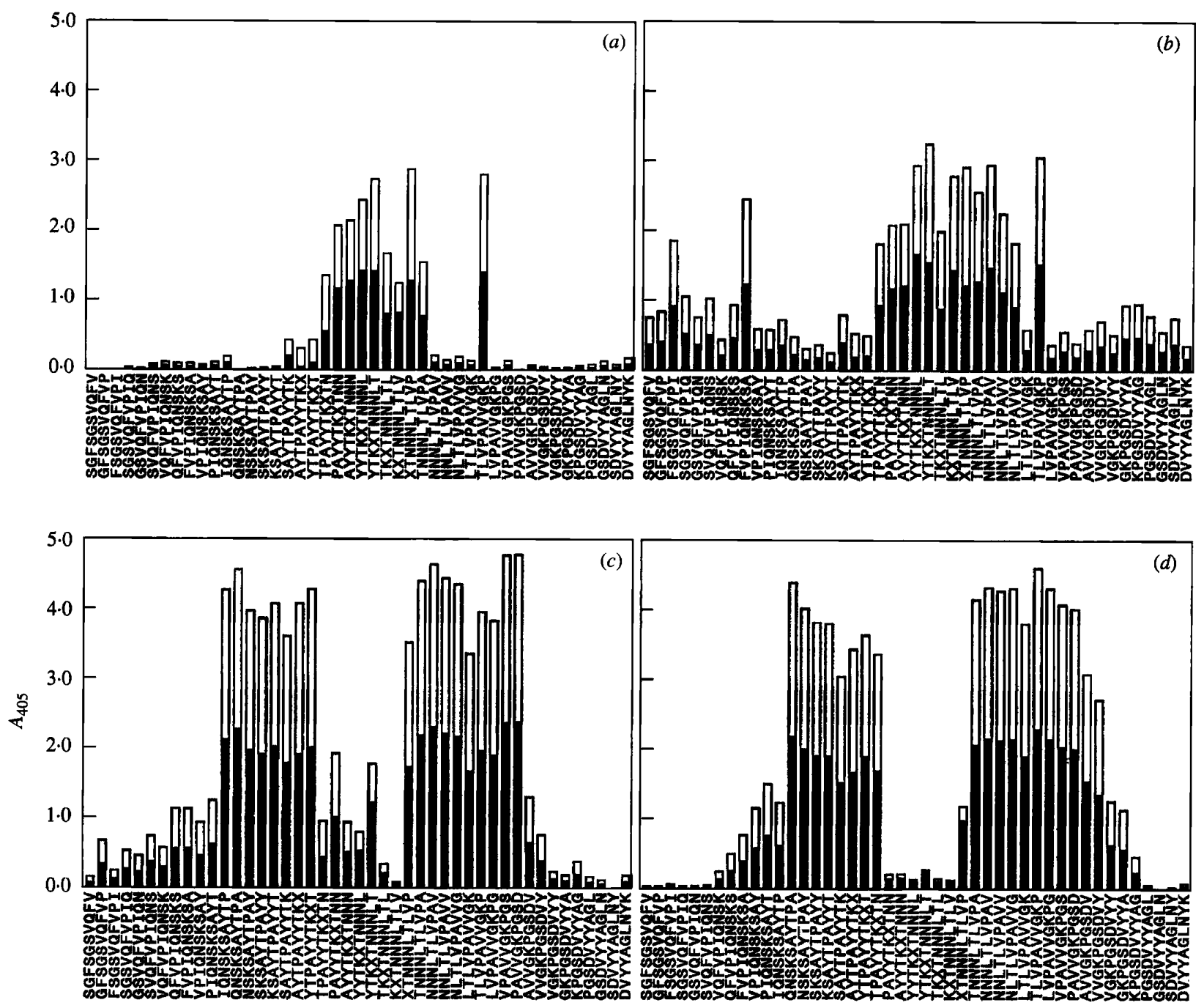

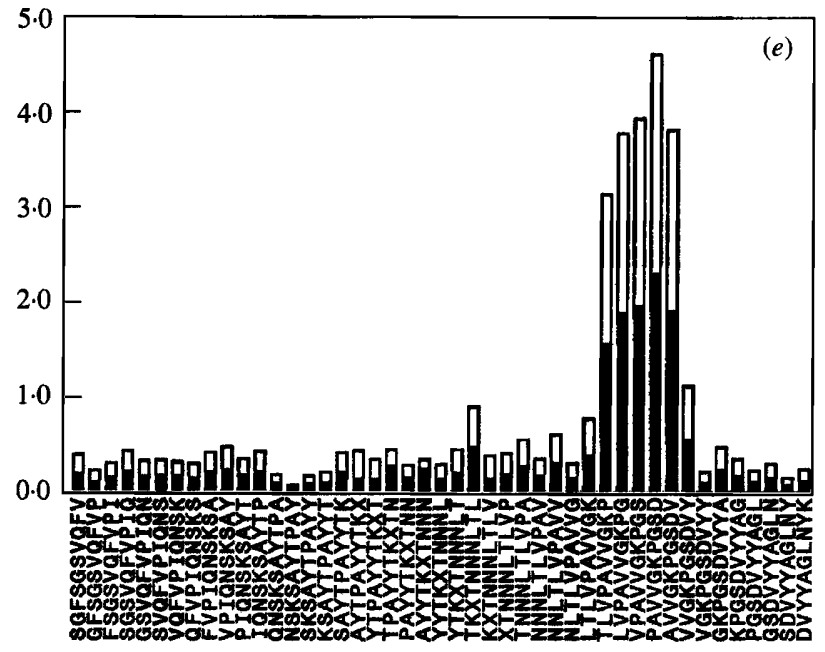

Peptide sequence

peptide also reacted over a broadly similar region (Fig. $1 b$ ). Both 9 mer and $15 \mathrm{mer}$ anti-peptide antisera reacted with the critical sequence ${ }^{180}$ TK $\underline{X}$ TNNNLTL ${ }^{189}$ (where
Fig. 1.Epitope mapping of antisera raised against synthetic peptides. Sera was reacted in ELISA with overlapping decapeptides corresponding to the amino acid sequence of loop 4 of the class 1 protein in which adjacent peptides differed by a single residue, and where residue $\mathrm{X}$ is either amino acid $\mathrm{N}$ (Pl.16b) or $\mathrm{D}(\mathrm{Pl} .16)$ at position 182. The absorbance of the corresponding pre-immune serum was subtracted as a background control. The sera used were raised against peptides 9N-KLH (a), 15N-KLH $(b), 36 \mathrm{~N}-\mathrm{KLH}(c), 36 \mathrm{~N}(d)$ and $\mathrm{C}-36 \mathrm{~N}(e)$, and were reacted with peptides corresponding to the $\mathrm{P} 1.16 \mathrm{~b}$ (filled bars) or P1.16 (open bars) epitopes.

$\underline{\mathrm{X}}$ is either $\mathrm{D}$ or $\mathrm{N}$ ). Essentially identical results were obtained with antisera raised against equivalent peptides synthesized with $\mathrm{D}^{182}$ replacing $\mathrm{N}^{182}$ (data not shown). 

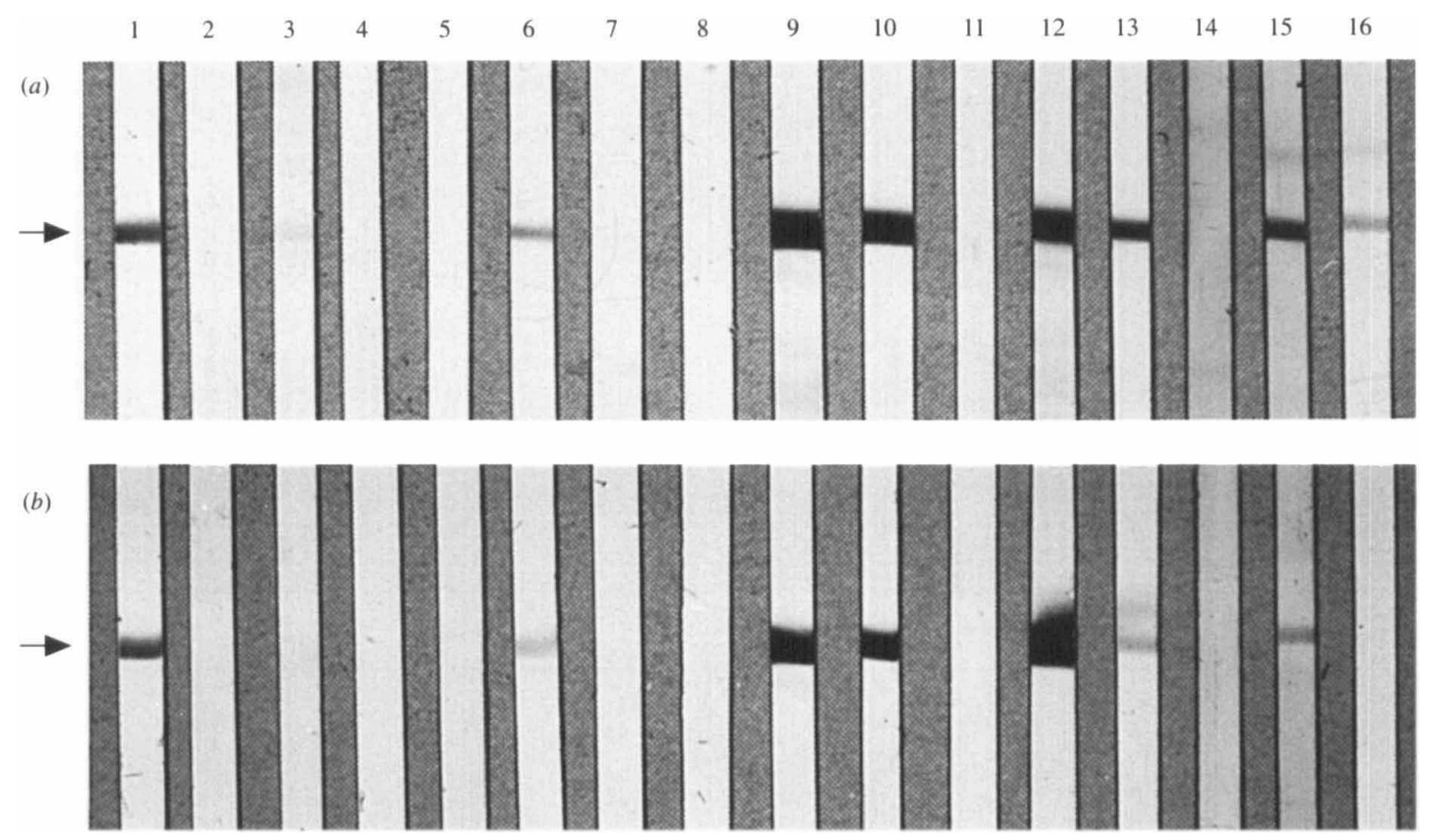

Fig. 2. Western blots of antisera obtained by immunization with synthetic peptides. Sera used were raised against peptides $9 \mathrm{~N}-\mathrm{KLH}$ (lanes 2-4), 15N-KLH (5-7), 36N-KLH (8-10), 36N (11-13) and C-36N (14-16), and were tested against (a) strain MC58 (P1.16b) and (b) strain MC50 (P1.16). In each panel, lane 1 shows the control with anti-class 1 protein $\mathrm{mAb}$ and within each set of three strips the first shows pre-immune sera at $1: 100$, and the second and third, antisera at $1: 100$ and $1: 1000$ dilutions, respectively. The arrows denote the position of the class 1 protein.

Immunization with the $36 \mathrm{mer}$ peptides produced completely different patterns of reactivity. The sera obtained on immunization with the $36 \mathrm{~N}-\mathrm{KLH}$ conjugate and the free $36 \mathrm{~N}$ peptide produced almost identical reactivity, recognizing two separate groups of peptides: ${ }^{167}{ }^{1 Q N S K S A Y T P}{ }^{176}$ through to ${ }^{174} Y$ TPAYYTKXT ${ }^{183}$ and ${ }^{182}$ XTNNNLTLVP ${ }^{191}$ through to ${ }^{191}$ PAVVGKPGSD ${ }^{200}$ (Fig. $1 c, d$ ). Little or no reactivity was seen with the peptides corresponding to the central region of the peptide, including the ${ }^{180}$ TKX $X N N N L T L{ }^{189}$ sequence recognized by all the sera raised against the $9 \mathrm{mer}$ and $15 \mathrm{mer}$ peptides. The antisera raised against cyclic peptide C-36N showed even more limited reactivity, reacting only with sequences corresponding to the C-terminal region, ${ }^{188} \mathrm{TLVPAVVGKP}^{197}$ to ${ }^{192} \mathrm{AVVGKPGSDV}^{201}$ (Fig. 1e). Again, no reactivity was observed with the ${ }^{180} \mathrm{TK} \underline{\mathrm{X} T N N N L T L}{ }^{189}$ sequence.

\section{Reactivity of antisera on Western blots}

The specificity of reactivity of all the anti-peptide antisera was also determined by Western blotting against OM preparations of meningococcal strains MC58 (Pl.16b) and MC50 (Pl.16) (Fig. 2a,b). Sera raised against the 9 mer peptide conjugate reacted weakly with the homologous class 1 protein of strain MC58 and not at all with heterologous strain MC50 (Fig. $2 a, b$ ). Peptide 15N$\mathrm{KLH}$ antisera showed weak reactivity at a dilution of $1: 100$ with the class 1 protein of both strains. Antisera raised against the $36 \mathrm{~N}-\mathrm{KLH}$ conjugate and the free $36 \mathrm{~N}$ peptides reacted strongly with the class 1 protein from both strains even at dilutions great than 1:10000 (not shown). Finally, antisera to the cyclic peptide C-36N reacted with the homologous class 1 protein of strain MC58 to a dilution of $1: 1000$, but more weakly with the heterologous strain MC50 (1:100 dilution).

\section{Bactericidal activity of anti-peptide antisera}

Antisera raised against synthetic peptides were tested for their ability to promote complement-mediated bactericidal killing of meningococcal strains MC58 (Pl.16b) and MC50 (Pl.16) using guinea pig serum as a complement source and with pre-immune serum as a control. The percentage killing by complement alone was assessed by comparison of c.f.u. in the presence of complement and decomplemented sera, and was consistently found to be less than $5 \%$ for MC50, and between 5 and $20 \%$ for MC58.

Antisera raised against peptides $9 \mathrm{~N}-\mathrm{KLH}, 15 \mathrm{~N}-\mathrm{KLH}$ and $36 \mathrm{~N}$ showed no bactericidal activity against either strain MC58 or MC50 (Table 3). Peptide 36N-KLH 
Table 3. Summary of the biological activities of antisera raised against synthetic peptides of the class 1 outer-membrane protein of Neisseria meningitidis

\begin{tabular}{|c|c|c|c|c|c|c|c|c|}
\hline \multirow[b]{2}{*}{$\begin{array}{l}\text { Peptide } \\
\text { immunogen }\end{array}$} & \multicolumn{4}{|c|}{ ELISA reactivity } & \multicolumn{2}{|c|}{$\begin{array}{c}\begin{array}{c}\text { Western } \\
\text { blot }\end{array} \\
\text { MC58 MC50 }\end{array}$} & \multicolumn{2}{|c|}{$\begin{array}{l}\text { Bactericidal } \\
\text { effect }\end{array}$} \\
\hline & $\begin{array}{l}\text { Homologous } \\
\text { peptide }\end{array}$ & $\begin{array}{c}\text { MC58 } 1 \\
\text { OM }\end{array}$ & $\begin{array}{c}\text { MC50 } \\
\text { OM }\end{array}$ & $\begin{array}{c}\mathrm{H} 44 / 76 \\
\mathrm{OM}\end{array}$ & $\begin{array}{c}\text { MC58 } \\
\text { OM }\end{array}$ & $\begin{array}{c}\mathrm{MC50} \\
\mathrm{OM}\end{array}$ & MC58 & MC50 \\
\hline 9N-KLH & + & + & + & + & $+1-$ & - & - & - \\
\hline $15 \mathrm{~N}-\mathrm{KLH}$ & + & + & + & + & $+1-$ & $+1-$ & - & - \\
\hline $36 \mathrm{~N}$ & + & + & + & + & + & + & - & - \\
\hline $36 \mathrm{~N}-\mathrm{KLH}$ & + & + & + & + & + & + & - & $+/-$ \\
\hline$C-36 N$ & + & $+1-$ & + & + & + & + & + & - \\
\hline
\end{tabular}

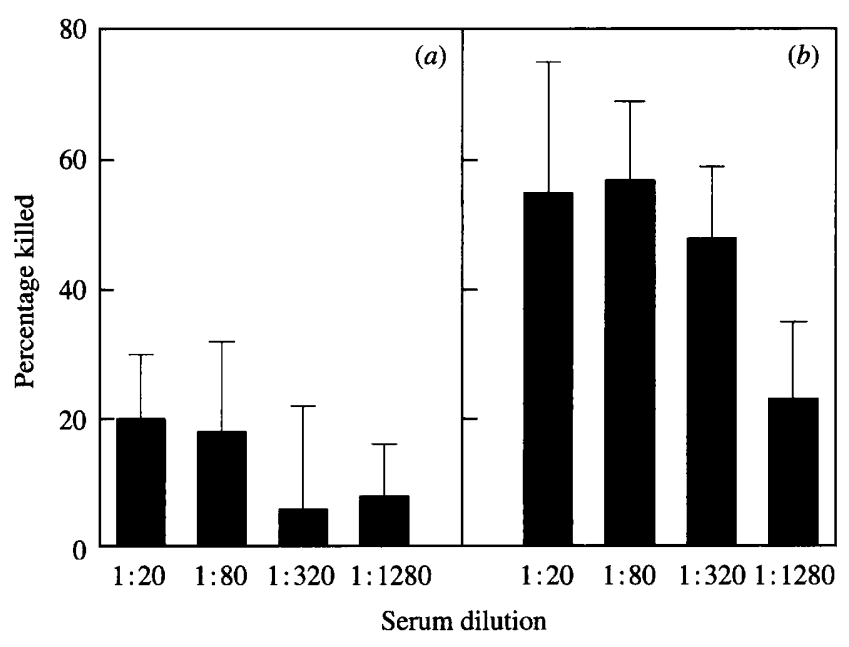

Fig. 3. Bactericidal effect of anti-peptide antisera. (a) Antiserum raised against $36 \mathrm{~N}-\mathrm{KLH}$ and bactericidal for strain MC50. (b) Antiserum raised against $\mathrm{C}-36 \mathrm{~N}$ and bactericidal for strain MC58. Results are expressed as the percentage c.f.u. surviving in the presence of antiserum and complement compared with controls containing preimmune serum and complement. Each serum was assayed six times at each serial dilution point, and the bars represent the mean and SD of the observed killing.

antiserum also demonstrated no bactericidal activity against the homologous strain MC58, but did show weak but statistically significant killing of strain MC50 at the higher concentrations (Fig. $3 a$ ). Bactericidal killing was significant $(P<0.05)$ at dilutions $1: 20(20 \%)$ and $1: 80$ $(18 \%)$. Antiserum raised against the cyclic peptide $\mathrm{C}-36 \mathrm{~N}$ showed clear bactericidal killing of the homologous strain MC58 at each of the concentrations tested, with a $50 \%$ end-point at a dilution of approximately $1: 320$ (Fig. $3 b$ ). With this antiserum, bactericidal activity could not be detected against the heterologous strain MC50.

\section{Discussion}

Recent field trials in humans with meningococcal vaccines based on outer-membrane proteins have demon- strated at least partial protection against group B infection. A large scale trial of an $\mathrm{OM}$ vesicle vaccine in Norwegian teenagers showed an efficacy of $57 \%$ (Bjune et al., 1991) and a similar level of protection has been observed in a field trial in Chile using macromolecular aggregates of outer-membrane proteins (Zollinger et al., 1991). Higher levels of protection $(83 \%)$ have been reported with a vesicle based vaccine used in mass immunization of teenagers in Cuba (Sierra et al., 1991), and of older children and adults (74\%) in São Paulo, Brazil (de Moraes et al., 1992). Such studies have demonstrated the potential protective effect induced by immunization with outer-membrane proteins but have also revealed that immunization induced a large proportion of non-functional antibodies, as measured by bactericidal effect, and that the protective effect did not persist. Consequently, an improved vaccine should direct immune responses towards those epitopes that induce bactericidal antibodies and a longer-lasting antibody response (Zollinger et al., 1991).

The ability to identify critical epitopes on proteins of infectious agents has prompted studies on the use of synthetic peptides for the induction of protective humoral and cell-mediated immune responses (Meloen et al., 1991). In a number of cases, potentially protective immune responses have been described, and, in at least one study with a synthetic malaria peptide, vaccination has been reported to produce protective immunity in human field trials (Amador et al., 1992). Such studies demonstrate the critical influence on antigenicity of discrete regions of the protein and permit investigation of the vaccine potential of synthetic peptides corresponding to epitopes recognized by the protective (monoclonal) antibodies. The observation that the class 1 protein epitopes recognized by the protective mAbs can be mapped to peptides corresponding to the sequence of the region thought to be exposed at the apex of the surface-exposed loop 4, suggests that this protein is a prime candidate for the use of related peptides as vaccine 
antigens. Indeed, synthetic peptides based on the related P1 porin of Neisseria gonorrhoeae have been demonstrated to be capable of inducing antibodies bactericidal for that organism (Heckels et al., 1990; Elkins et al., 1992). In the current study, therefore, several synthetic peptides encompassing the P1.16b epitope were synthesized with the initial aim of inducing a polyclonal response closely resembling the reactivity of the mAbs.

Previous epitope mapping studies have revealed the epitopes recognized by three distinct P1.16-specific mAbs to be the overlapping peptides ${ }^{181} \mathrm{KDTNNN}{ }^{186}$, ${ }^{181} \mathrm{KDTNNNL}^{187}$ and ${ }^{180}$ TKDTNNNLTL ${ }^{189}$, respectively, whilst the corresponding peptides from the mutant strain containing the $\mathrm{N}^{182}$ substitution failed to react (McGuinness et al., 1990, 1991). The small 9mer peptide was therefore synthesized to contain the P1.16b sequence equivalent to the minimal hexapeptide epitope $\left({ }^{181} \mathrm{KNTNNN}{ }^{186}\right)$ with one amino acid flanking each end and with the addition of a $\mathrm{C}$-terminal cysteine for coupling to a carrier protein. The intermediate $15 \mathrm{mer}$ peptide was synthesized to contain the equivalent maximal decapeptide epitope ${ }^{180}$ TKNTNNNLTL ${ }^{189}$ and with the rationale that the immune response may be directed mainly towards the $\mathrm{N}$ terminus of a coupled peptide, and not to the $\mathrm{C}$ terminus because of steric hindrance by the carrier protein (Heckels et al. 1990).

Both peptide conjugates were highly immunogenic, inducing specific anti-peptide responses. Also, the patterns of reactivity of the polyclonal sera with synthetic decapeptides were similar to that seen in the previous epitope mapping experiments with $\mathrm{mAbs}$, in that both sera reacted with the decapeptide containing the maximal epitope. In addition, a high degree of cross-reactivity was observed for the equivalent peptides containing the $\mathrm{D}$ residue at position 182. However, despite this induction of antibodies apparently having the desired specificity, the antisera showed limited recognition of the native protein, as revealed by their reactivity with OMs and, even more importantly, there was no bactericidal effect.

Polyclonal antisera raised against synthetic peptides are likely to contain antibodies to a wide range of conformations adopted by the peptide(s) in free solution, only a fraction of which may be relevant to the stable conformation of the native protein (Arnon, 1991). Since it appeared that the 9mer and 15mer peptides induced only a minority of antibodies capable of recognizing the native protein, alternative strategies were adopted in an attempt to induce more conformationally relevant antibodies. A larger 36mer peptide, consisting of the surface-exposed loop 4 of the class I protein and containing the $\mathrm{N}^{182}$ residue, was synthesized in the expectation that intra-molecular interactions might cause it to adopt sufficient conformation in solution to mimic that of the native protein. In addition, the peptide was also subjected to cyclization in an attempt to restrict it further to conformations that might even more closely resemble the native loop structure.

The patterns of reactivity of sera raised against the free $36 \mathrm{~N}$ peptide and the $36 \mathrm{~N}-\mathrm{KLH}$ conjugate were similar, but also quite distinct from the reactivity of sera obtained with the smaller peptides. In both cases there was reactivity for sequences flanking the critical loop apex and the sera failed to react with the maximal decapeptide epitope. The sera obtained with the cyclic C-36N peptide showed even more restricted reactivity with the decapeptides, recognizing only those corresponding to the Cterminal residues. Despite this failure to induce an immune response which mimicked the epitope mapping pattern of the protective mAbs, all sera raised with the 36 mer peptides showed significant reactivity with native protein in OMs.

It is generally accepted that the aim of a potential vaccine against group $B$ meningococci should be to induce an effective complement-mediated bactericidal response (Frasch, 1985), since this activity correlates with immunity to infection (Goldschneider et al., 1969). Therefore, the key property of all the sera raised during the current work was the bactericidal effect of the sera raised against the conjugated and cyclic 36 mer peptides. Sera raised against the conjugated peptide showed limited but statistically significant bactericidal activity, whilst that raised against the cyclic peptide was particularly effective, producing $50 \%$ killing down to a dilution of $1: 320$. The protection observed with the cyclic peptide was confined to bactericidal activity against the homologous, mutant strain. No equivalent effect was observed against the wild-type strain containing the $\mathrm{D}^{182}$ residue, which presumably reflects a lower affinity of the antibodies induced, for the heterologous strain.

In this study, no direct correlation could be drawn between serum bactericidal activity against meningococci and serum reactivity for solid-phase peptides or indeed even with OMs. The reactivity of polyclonal sera raised against smaller peptides, for the maximal mAb-reactive epitope (TKX $\underline{X}$ TNNNLTL), probably reflects immune responses directed towards linear determinants, which are likely to be favoured by these peptides in solution. Thus, these peptides induced sera that presumably contain a large proportion of non-functional and conformationally irrelevant antibodies, and are nonbactericidal. Conversely, the non-reactivity of polyclonal sera raised against the large loop 4 peptides, for the mAb-reactive epitope, may indicate that the peptides elicit an antibody response directed towards a stable conformational epitope which cannot be mapped on linear peptides. Therefore, these peptides presumably induce functional and conformationally relevant anti- 
bodies able to react with the class 1 protein at the surface of the meningococcus, and are bactericidal. These observations clearly indicate the importance of relevant biological assays rather than simple serum reactivity with OMs in ELISA, and reveal that even detailed epitope mapping with oligopeptides may have limited relevance for polyclonal antisera that recognize conformational determinants.

Thus, the most promising peptide vaccine candidate is the large peptide which has been conformationally restricted by cyclization, in an attempt to mimic the surface-exposed loop 4 of the class 1 protein. The peptide was sufficiently immunogenic without conjugation to a carrier protein, suggesting the presence of an effective Th-cell epitope(s) in addition to the protective B-cell epitope. This would be in accord with recent observations that peptides corresponding to regions of this sequence also induced significant proliferative responses of peripheral blood mononuclear cells from immune human volunteers (Wiertz et al., 1992). The occurrence of homologous T-cell epitopes within the immunizing peptide would be particularly important for triggering immunological memory in immunized individuals who subsequently encounter meningococcal infection. This current study, therefore, represents the first report of a synthetic immunogen capable of inducing an immune response, protective in vitro, against group B meningococci and demonstrates the critical importance of the conformation of the immunogen. Further studies on the vaccine potential of this, and related, peptide(s) are likely to involve more precise conformational restrictions, with the aim of producing a series of conformationally constrained immunogens which, with increasing accuracy, mimic the three-dimensional structure of the native protein. Although experiments designed to enhance immunogenicity with appropriate adjuvants would also be required before consideration for human use of such vaccines, the current studies show the potential of synthetic peptides for the production of protective immune responses against Neisseria meningitidis.

This work was supported by the National Meningitis Trust and by the Medical Research Council. B. M. was supported by a MRC Research Studentship. We are grateful to Dr J. McCandless, Applied Biosystems, for the mass spectroscopy of cyclic peptides.

\section{References}

Amador, R., Moreno, A., Valero, V., Murillo, L., Mora, A. L., Rojas, M., Rocha, C., Salcedo, M, Guzman, F., Espejo, F., Nunez, F. \& Patarroyo, M. E. (1992). The first field trials of the chemically synthesized malaria vaccine SPf66: safety, immunogenicity and protectivity. Vaccine 10, 179-184.

ARNON, R. (1991). Synthetic peptides as the basis for vaccine design. Molecular Immunology 28, 209-215.

Buune, G., Hoiby, E. A., Gronnesby, J. K., Arnesen, O., Fredriksen, J. H., Halstensen, A., Holten, E., LindbaK, A. K., Nokleby, H.,
Rosenqvist, E., Solberg, L. K., Closs, O., Eng, J., Froholm, L. O., LySTAD, A., BAKKeTEIG, L. S. \& HAREIDE, B. (1991). Effect of outermembrane vesicle vaccine against group-B meningococcal disease in Norway. Lancet 338, 1093-1096.

Elkins, C., Carbonetti, N. H., Varela, V. A., Stirewalt, D., KLAPPER, D. G. \& SPARLING, P. F. (1992). Antibodies to N-terminal peptides of gonococcal porin are bactericidal when gonococcal lipopolysaccharide is not sialylated. Molecular Microbiology 6, $2617-2628$.

FrasCH, C. E. (1985). Status of a group-B Neisseria meningitidis vaccine. European Journal of Clinical Microbiology 4, 533-536.

Frasch, C. E., Zollinger, W. D. \& Poolman, J. T. (1985). Serotype antigens of Neisseria meningitidis and a proposed scheme for designation of serotypes. Review of Infectious Diseases 7, 504-510.

Geysen, H. M., Rodda, S. J., Mason, T. J., Tribick, G. \& Schoofs, P. G. (1987). Strategies for epitope analysis using peptide synthesis. Journal of Immunological Methods 102, 259-274.

GoldsChNeIDER, I., Gotschlich, E. C. \& ARTENSTEIN, M. S. (1969). Human immunity to the meningococcus. II. Development of natural immunity. Journal of Experimental Medicine 129, 1327-1348.

HeCkels, J. E. (1981). Structural comparison of Neisseria gonorrhoeae outer-membrane proteins. Journal of Bacteriology 145, 736-742.

HeCkels, J. E., VIRI, M. \& TINSLEY, C. R. (1990). Vaccination against gonorrhoea - the potential protective effect of immunization with a synthetic peptide containing a conserved epitope of gonococcal outer membrane protein Ib. Vaccine 8, 225-230.

LAMbden, P. R., Robertson, J. N. \& WATT, P. J. (1981). The preparation and properties of $\alpha$-pili and $\beta$-pili from variants of Neisseria gonorrhoeae P9. Journal of General Microbiology 124, 109-117.

van der Ley, P., Heckels, J. E., VirJi, M., Hoogerhout, P. \& Poolman, J. T. (1991). Topology of outer-membrane porins in pathogenic Neisseria spp. Infection and Immunity 59, 2963-2971.

McGuinness, B. T., Barlow, A. K., Clarke, I. N., Farley, J. E., Anilionis, A. Poolman, J. T. \& Heckels, J. E. (1990). Deduced amino acid sequences of class 1 protein (PorA) from 3 strains of Neisseria meningitidis - synthetic peptides define the epitopes responsible for serosubtype specificity. Journal of Experimental Medicine 171, 1871-1882.

McGuinness, B. T., Clarke, I. N., Lambden, P. R., Barlow, A. K., Poolman, J. T., Jones, D. M. \& Heckels, J. E. (1991). Point mutation in meningococcal por $A$ gene associated with increased endemic disease. Lancet 337, 514-517.

McGuinness, B. T., Lambden, P. R. \& Heckels, J. E. (1993). Class 1 outer membrane protein of Neisseria meningitidis: epitope analysis of the antigenic diversity between strains, implications for subtype definition and molecular epidemiology. Molecular Microbiology, 7, 505-514.

Maiden, M. C. J., Suker, J., McKenna, A. J., Bygraves, J. A. \& FEAVERS, I. M. (1991). Comparison of the class 1 outer membrane proteins of 8 serological reference strains of Neisseria meningitidis. Molecular Microbiology 5, 727-736.

Meloen, R. H, Amerongen, M., Hage-van Noort, M., LangediJK, J. P. M., Posthumus, W. P. A., Puyk, W. C., Lenstra, J. A. \& LANGEVELD, J. P. M. (1991). The use of peptides to reconstruct conformational determinants: a brief review. Annales De Biologie Clinique 49, 231-242.

de Moraes, J. C., Perkins, B. A., Camargo, M. C. C., Hidalgo, N. T. R., Barbosa, H. A., Sacchi, C. T., Gral, I. M. L., Gattas, V. L., Vasconcelos, H. D., Plikaytis, B. D., Wenger, J. D. \& Broome, C. V. (1992). Protective efficacy of a serogroup-B meningococcal vaccine in Sao-Paulo, Brazil. Lancet 340, 1074 1078

Munkley, A., Tinsley, C. R., ViRJi, M. \& Heckels, J. E. (1991). Blocking of bactericidal killing of Neisseria meningitidis by antibodies directed against class 4 outer membrane protein. Microbial Pathogenesis 11, 447-452.

Saukkonen, K., Leinonen, M., Abdillahi, H. \& Poolman, J. T. (1989). Comparative evaluation of potential components for group B meningococcal vaccine by passive protection in the infant rat in vitro bactericidal assay. Vaccine 7, 325-328.

Sierra, G. V. G., Campa, H. C., Varcacel, N. M., Garcia, I. L., 
Izquierdo, P. L., Sotolongo, P. F., Casanueva, G. V., Rico, C. O., RoDrigueZ, C. R. \& TERRY, M. H. (1991). Vaccine against group B Neisseria meningitidis: protection trial and mass vaccination results in Cuba. NIPH Annals 14, 195-210.

TAM, J. P. \& LU, Y. A. (1989). Vaccine engineering: enhancement of immunogenicity of synthetic peptide vaccines related to hepatitis in chemically defined models consisting of T-cell and B-cell epitopes. Proceedings of the National Academy of Sciences of the United States of America 86, 9084-9088.

TinsLeY, C. R. \& HeCkels, J. E. (1986). Variation in the expression of pili and outer-membrane protein by Neisseria meningitidis during the course of meningococcal infection. Journal of General Microbiology 132, 2483-2490.

Tsai, C. M., Frasch, C. E. \& Mocca, L. F. (1981). Five structural classes of major outer membrane proteins in Neisseria meningitidis. Journal of Bacteriology 146, 69-78.

VIRJI, M. \& HECKELS, J. E. (1989). Location of a blocking epitope on outer-membrane protein-III of Neisseria gonorrhoeae by synthetic peptide analysis. Journal of General Microbiology 135, 1895-1899.

WEDEGE, E. \& FROHOLM, L. O. (1986). Human-antibody response to a group-B serotype 2 a meningococcal vaccine determined by immunoblotting. Infection and Immunity 51, 571-578.

WierTz, E. J. H. J., Van GaAns-Van den Brink, J. A. M., Gausepohl, H., Prochnicka-Chalufour, A., Hoogerhout, P. \& Poolman, J. T. (1992). Identification of T-cell epitopes occurring in a meningococcal class 1 outer membrane protein using overlapping peptides assembled with simultaneous multiple peptide-synthesis. Journal of Experimental Medicine 176, 79-88.

Zollinger, W., Boslego, J., Moran, E., Garcia, J., Rutz, S., Brandt, B., Martinez, M., ARTHUR, J., UnderwoOd, P., Hankins, W., Mays, J., Gilly, J. \& the Chilean National Committee for MENINGOCOCCAL Disease. (1991). Meningococcal serogroup B vaccine: protection trial and follow-up studies in Chile. NIPH Annals 14, 211-213. 